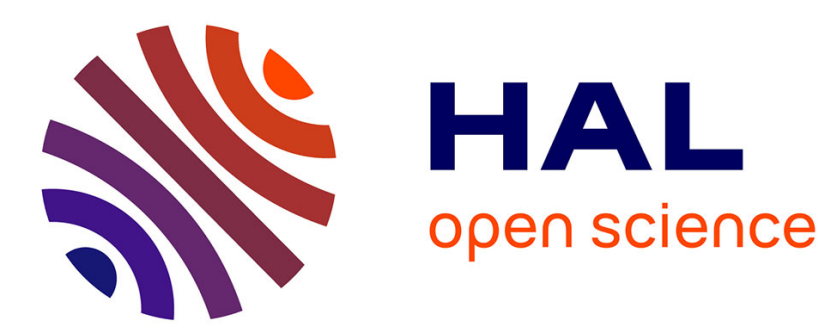

\title{
Residues of the fungicide famoxadone in grapes and its fate during wine production
}

Vincenzo Garau, Susana de Melo Abreu, Pierluigi Caboni, Paolo Cabras, Arminda Alves, Filippo Pirisi

\section{To cite this version:}

Vincenzo Garau, Susana de Melo Abreu, Pierluigi Caboni, Paolo Cabras, Arminda Alves, et al.. Residues of the fungicide famoxadone in grapes and its fate during wine production. Food Additives and Contaminants, 2006, 23 (03), pp.289. 10.1080/02652030500428648 . hal-00577571

\section{HAL Id: hal-00577571 \\ https://hal.science/hal-00577571}

Submitted on 17 Mar 2011

HAL is a multi-disciplinary open access archive for the deposit and dissemination of scientific research documents, whether they are published or not. The documents may come from teaching and research institutions in France or abroad, or from public or private research centers.
L'archive ouverte pluridisciplinaire HAL, est destinée au dépôt et à la diffusion de documents scientifiques de niveau recherche, publiés ou non, émanant des établissements d'enseignement et de recherche français ou étrangers, des laboratoires publics ou privés. 


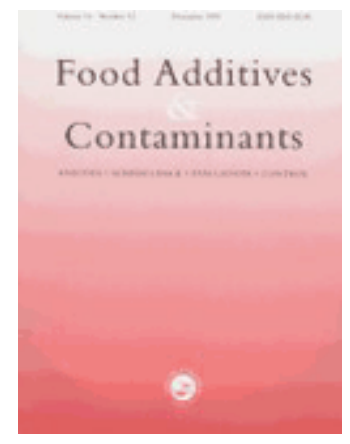

\section{Residues of the fungicide famoxadone in grapes and its fate during wine production}

\begin{tabular}{|r|l|}
\hline Journal: & Food Additives and Contaminants \\
\hline Manuscript ID: & TFAC-2005-141.R1 \\
\hline Manuscript Type: & Original Research Paper \\
\hline Author: & $19-$ Oct-2005 \\
\hline Complete List of Authors: & $\begin{array}{l}\text { Garau, Vincenzo; University of Cagliari, Dipartimento di Tossicologia } \\
\text { de Melo abreu, Susana; Faculdade de Engenharia da Universidade } \\
\text { do Porto, LEPAE-DEQ } \\
\text { Caboni, Pierluigi; University of Cagliari, Dipartimento di Tossicologia } \\
\text { Cabras, Paolo; University of Cagliari, Dipartimento di Tossicologia } \\
\text { Alves, Arminda; Faculdade de Engenharia da Universidade do Porto, } \\
\text { LEPAE-DEQ } \\
\text { Pirisi, Filippo; University of Cagliari, Dipartimento di Tossicologia }\end{array}$ \\
\hline Methods/Techniques: & GC/MS, Extraction \\
\hline Additives/Contaminants: & Pesticide residues \\
\hline Food Types: & Beverages, Fruit \\
\hline & \\
\hline
\end{tabular}

\section{SCHOLARONE" \\ Manuscripts}


1 Table 1. Concentration of famoxadone during grapes maturation, expressed by means of a relative 2 standard deviation (SD).

3

\begin{tabular}{ccc}
\hline Days after treatment & Concentration $\left(\mathbf{m g ~ k g}^{-\mathbf{1}}\right) \mathbf{E S D}$ & $\mathbf{t}_{\mathbf{1} / \mathbf{2}}$ (days) \\
\hline 0 & $0.27 \pm 0.06$ & \\
\hline 3 & $0.40 \pm 0.11$ & \\
\hline 7 & $0.30 \pm 0.12$ & 18 \\
\hline 14 & $0.22 \pm 0.11$ & \\
\hline 21 & $0.14 \pm 0.10$ \\
\hline 28 & $0.16 \pm 0.07$ & \\
\hline
\end{tabular}

4

5

6

7

8

9

10

11

12

13

14

15

16

17

18 
20 Table 2. Fate of famoxadone during wine production.

21

\begin{tabular}{|c|c|c|}
\hline Sample & \multicolumn{2}{|c|}{ Concentration $\left(\mu \mathrm{g} \mathrm{kg}^{-1}\right.$ or $\left.\mu \mathrm{g} \mathrm{l}^{-1} \pm \mathrm{SD}\right)$} \\
\hline Grapes & \multicolumn{2}{|c|}{$0.27 \pm 0.06$} \\
\hline Must & \multicolumn{2}{|c|}{$0.33 \pm 0.03$} \\
\hline Vinification without maceration & \multicolumn{2}{|c|}{ Vinification with maceration } \\
\hline $0.31 \pm 0.04$ & Wine & <L.O.D. \\
\hline$<$ L.O.D. & \multirow{2}{*}{$\begin{array}{c}\text { Cake and lees } \\
(32.5 \%)\end{array}$} & \multirow{2}{*}{$0.67 \pm 0.17$} \\
\hline Lees $(5.8 \%)$ & & \\
\hline
\end{tabular}

22

23

24

25

26

27

28

29

30

31

32

33

34

35 
36 Table 3. Results of Tests A (evaporation and thermodegradation) and B (codistillation) for the 37 famoxadone active ingredient, expressed in $\mu \mathrm{g} \mathrm{cm}^{-2} \pm \mathrm{SD}$.

38

\begin{tabular}{ccccc}
\hline & \multicolumn{2}{c}{ Test A } & \multicolumn{2}{c}{ Test B } \\
\cline { 2 - 5 } & $\begin{array}{c}\text { without } \\
\text { waxes }\end{array}$ & with waxes & $\begin{array}{c}\text { without } \\
\text { waxes }\end{array}$ & with waxes \\
\hline Control sample (c) & $2.00 \pm 0.06$ & $1.40 \pm 0.34$ & $2.10 \pm 0.20$ & $1.70 \pm 0.15$ \\
\hline Vial (v) & $<$ LOD & $<$ LOD & - & - \\
\hline Membrane (m) & $2.00 \pm 0.26$ & $1.40 \pm 0.29$ & $1.90 \pm 0.33$ & $1.80 \pm 0.10$ \\
\hline $\mathbf{c}-(\mathbf{v}+\mathbf{m})$ & n.s. & n.s. & n.s. & n.s. \\
\hline
\end{tabular}

39

n.s. - not significant

40

41

42

43

44

45

46

47

48

49

50

51

52

53

54 
56 Table 4. Results of Tests A (evaporation and thermodegradation) and B (codistillation) for the 57 commercial product Equation Pro, expressed in $\mu \mathrm{g} \mathrm{cm}^{-2} \pm \mathrm{SD}$.

58

\begin{tabular}{ccccc}
\hline & \multicolumn{2}{c}{ Test A } & \multicolumn{2}{c}{ Test B } \\
\cline { 2 - 5 } & $\begin{array}{c}\text { without } \\
\text { waxes }\end{array}$ & with waxes & $\begin{array}{c}\text { without } \\
\text { waxes }\end{array}$ & with waxes \\
\hline Control sample (c) & $1.34 \pm 0.01$ & $1.69 \pm 0.07$ & $1.43 \pm 0.05$ & $1.63 \pm 0.06$ \\
\hline Vial (v) & $<$ LOD & $<$ LOD & - & - \\
\hline Membrane (m) & $1.34 \pm 0.02$ & $1.61 \pm 0.15$ & $1.44 \pm 0.05$ & $1.61 \pm 0.05$ \\
\hline c $-(\mathbf{v}+\mathbf{m})$ & n.s. & n.s. & n.s. & n.s. \\
\hline
\end{tabular}

59

n.s. - not significant

60

61

62

63

64

65

66

67

68

69

70

71

72

73

74 
76 Table 5. Results of Tests C (sunlight photodegradation) for the famoxadone active ingredient, 77 expressed in $\mu \mathrm{g} \mathrm{cm}^{-2} \pm \mathrm{SD}$.

78

\begin{tabular}{lcc}
\hline & \multicolumn{2}{c}{ Test $\mathbf{C}$} \\
\cline { 2 - 3 } & without waxes & with waxes \\
\hline $\mathbf{t}_{\mathbf{1} / \mathbf{2}}$ (days) & 4.41 & 4.26 \\
\hline $\mathbf{R}^{\mathbf{2}}$ & 0.77 & 0.99 \\
\hline
\end{tabular}

79

80

81

82

83

84

85

86

87

88

89

90

91

92

93

94

95

59

60

96 
97 Table 6. Results of Tests C (sunlight photodegradation) for the commercial product Equation Pro, 98 expressed in $\mu \mathrm{g} \mathrm{cm}^{-2} \pm \mathrm{SD}$.

99

\begin{tabular}{lcc}
\hline & \multicolumn{2}{c}{ Test $\mathbf{C}$} \\
\cline { 2 - 3 } & without waxes & with waxes \\
\hline $\mathbf{t}_{\mathbf{1} / \mathbf{2}}$ (days) & 3.75 & 4.61 \\
\hline $\mathbf{R}^{\mathbf{2}}$ & 0.91 & 0.97 \\
\hline
\end{tabular}

100

101

25

26

27

28

29

30 
1 Residues of the fungicide famoxadone in grapes and its fate during wine 2 production 3 Susana de Melo Abreu ${ }^{\dagger}$, Pierluigi Caboni ${ }^{\ddagger}$, Filippo Maria Pirisi ${ }^{\ddagger}$, Paolo Cabras ${ }^{\ddagger}$, Arminda Alves ${ }^{\dagger}$, \& Vincenzo Luigi Garau ${ }^{* \dagger}$

6

$7{ }^{\dagger}$ LEPAE-DEQ, Faculdade de Engenharia da Universidade do Porto, Rua Dr. Roberto Frias, 4200-

8465 Porto, Portugal.

9 \# Dipartimento di Tossicologia, Università di Cagliari, Via Ospedale, 72, 09124 Cagliari, Italy. 10

11 * Correspondence: Prof Vincenzo Luigi Garau. E-mail: vlgarau@unica.it

12 
28 Abstract

29 Famoxadone is a recently applied fungicide to vines, belongings the oxazolidinedione family. In 30 this work, the fate of famoxadone was studied considering the decay ratio of this fungicide during 31 grapes maturation and wine production. The main factors affecting the presence of fungicide 32 residues such as fruit growth, photodegradation, evaporation, thermodegradation, and co33 distillation were studied with model systems.

34 An experimental field was treated with a commercial product containing famoxadone at the 35 recommended dose. After this application, residues of famoxadone were found in grapes at the 36 concentration of $0.27 \pm 0.06 \mathrm{mg} \mathrm{kg}^{-1}$. In this field experiment, the half-life time $\left(\mathrm{t} \frac{1}{1 / 2}\right)$ of 37 famoxadone, described as pseudo-first-order kinetics $\left(\mathrm{R}^{2}=0.74\right)$, was $18 \pm 6$ days, resulting from 38 the photodegradation. The famoxadone residue levels in grapes were below the established 39 Maximum Residues Level (MRL) for Europe $\left(2 \mathrm{mg} \mathrm{kg}^{-1}\right)$ whilst levels in wine, carried out with 40 and without maceration, were below the calculated limit of detection (LOD) of the method.

42 Keywords: famoxadone residues; grapes; wine production; model systems. 


\section{Introduction}

54 Famoxadone (3-anilino-5-methyl-5-(4-phenoxyphenyl)-1,3-oxazolidine-2,4-dione) is a recently 55 developed highly active and broad spectrum fungicide used to control different crop diseases. In 56 viniculture, the commercial formulation, named Equation Pro and manufactured by Dupont Crop 57 Protection, is applied to bunch and leaves to control downy mildew, which is an important 58 grapevine disease induced by the Plasmopora viticola (Joshi and Sternberg 1996). The chemistry 59 and biochemical mode of action of famoxadone is close to the known class of strobilurins (Bartlett 60 et al. 2002). The fungicidal activity of famoxadone consists in the inhibition of the mitochondrial 61 respiration by binding at the so-called $\mathrm{Q}_{0}$ site of cytochrome $\mathrm{b}$, located in the inner mitochondrial 62 membrane of the fungi (Jordan et al. 1999).

64 Famoxadone active ingredient can be used on grapes in Europe at a maximum application rate of $650.05 \mathrm{~kg} \mathrm{ha}^{-1}$ (France and Greece), $0.09 \mathrm{~kg} \mathrm{ha}^{-1}$ (Italy and Spain) or $0.14 \mathrm{~kg} \mathrm{ha}^{-1}$ (Germany). Spain 66 and Greece allow a maximum of 6 applications per season and the other countries a maximum of 3 67 applications, except Germany (8). In Italy the maximum residue level (MRL) for famoxadone is 2 $68 \mathrm{mg} \mathrm{kg}^{-1}$ with a safety interval (PHI) of 28 days

69 (http://www.fao.org/documents/show_cdr.asp?url_file=/DOCREP/006/Y5221E/y5221e0e.htm).

70 The first analytical method reported in the literature to determine famoxadone in grapes and wine 71 used liquid-liquid extraction (LLE) and gel permeation chromatography (GPC) before a gas 72 chromatographic separation with electron capture detection (GC-ECD) (Jernberg 2003). Our group 73 validated one method by GC/MS, using a simple and fast LLE procedure (de Melo Abreu et al. 74 2005). This method was used in the present work. To our knowledge no studies reported the fate of 
75 famoxadone from vine to wine. The application of the active ingredient close to the grapes harvest 76 could lead to the presence of famoxadone residues in wine.

Different papers (Cabras et al. 1997, 1998, 2001; Garau et al. 2002) deal with the persistence and 79 the study of the mechanism of disappearance of pesticides with model systems in grapes and wine 80 production. Following treatment, pesticides spread into the epicuticular waxes present on fruits 81 surface and could affect the degradative process of the active ingredient (Cabras et al. 1997). This 82 paper aims to contribute to the knowledge of the persistence of famoxadone in grapes and its 83 behaviour during wine production.

\section{Experimental}

\section{$86 \quad$ Fungicide treatment}

87 The trial was carried out in a farm located in Santadi (Cagliari, Italy), in 240 vines of the vitis 88 variety Carignano, with a plant spacing of $1.9 \mathrm{~m} \times 0.8 \mathrm{~m}$. The treatment with the commercial 89 formulation Equation Pro, containing $22.5 \%$ of famoxadone, was done September 2, 2004. A 90 random block scheme with 4 replications for each test was used. Each block contained 60 vines.

91 The fungicide application was carried out with the dose recommended by the manufacturer ( $480 \mathrm{~g}$ $92 \mathrm{ha}^{-1}$ ), using a Carpi portable motor sprayer (Modena, Italy).

94 The weather conditions were continuously recorded with a Silimet AD-2 automatic station 95 (Modena, Italy), with an average total rainfall of $0.7 \mathrm{~mm}$, a minimum temperature of $17.1^{\circ} \mathrm{C}$, a 96 maximum temperature of $30.2^{\circ} \mathrm{C}$, and an average solar radiation of 167 watt $\mathrm{m}^{2}$.

Grapes material and wine production 
99 Samplings of $2 \mathrm{~kg}$ of dry stemmed black grapes were taken. The first collection was carried out on 100 September 2, before and after fungicide treatment. Then, the grapes were collected after 3, 7, 14, 10121 and 28 days. In the wine production, each grape sample was divided in two portions, both of 102 them pressed and added with $200 \mathrm{mg}$ of sodium metabisulphite. One portion was fermented with 103 skin, for the vinification with maceration process, and the other without skin, being called 104 vinification without maceration process. To improve the fermentation process, $20 \mathrm{mg} \mathrm{kg}^{-1}$ of active 105 dry yeasts was added.

The amount of the famoxadone residues during the grapes maturation and wine-making was 108 determined. Crushed grape samples were directly analysed as described below. An aliquot of $100 \mathrm{~g}$ 109 of must was centrifuged at $4000 \mathrm{rpm}$ for $5 \mathrm{~min}$, the amount of cake and the concentration of 110 famoxadone residues in the cake and in the clear must were measured. Fermentation had been a 111 regular course in all samples and, after 15 days, the obtained wines were centrifuged in the same 112 manner as must and analysed. At the end of the vinification process without maceration, lees 113 amount and famoxadone residues were measured. In vinification process with maceration, after the 114 wine had been made, the amount of cake with lees, and famoxadone residues were measured.

\section{Chemicals}

117 The commercial formulation Equation Pro (22.5\% of famoxadone and $30.0 \%$ of cimoxanil) and 118 the analytical standard of famoxadone (99.4\%) were obtained from Dupont Crop Protection 119 (Newark, USA). Acetonitrile LiChrosolv isocratic grade for GC ( $\geq 99.8 \%)$ and chloroform 120 Normapur for GC $(\geq 99.0 \%)$ were purchased from Merck (Darmstadt, Germany). Hexane $121(\geq 95.0 \%)$, ethyl acetate $(\geq 99.8 \%)$ and acetone $(\geq 99.8 \%)$ were Pestanal Grade for residues analysis 122 from Riedel-de Haën (Seelze, Germany). The water was bidistillated and filtered with a Millipore 
Standards preparation

126 A fungicide stock solution $\left(1 \mathrm{~g} \mathrm{l}^{-1}\right)$, and a working solution $\left(100 \mathrm{mg} \mathrm{l}^{-1}\right)$ were prepared in 127 acetonitrile and stored in dark glass vials, and kept respectively at $-20{ }^{\circ} \mathrm{C}$ and $4{ }^{\circ} \mathrm{C}$. Appropriate 128 standards solutions for control quality assessment were made daily as described elsewhere (de 129 Melo Abreu et al., 2005).

131 Sample extraction

132 For extraction, crushed grapes $(5 \mathrm{~g})$, must and wine $(5 \mathrm{ml})$ samples were weighed in $40 \mathrm{ml}$ screw133 capped tubes and $10 \mathrm{ml}$ of ethyl acetate/hexane $(50: 50 \mathrm{v} / \mathrm{v})$ was added. Tubes containing the 134 mixture were agitated for $15 \mathrm{~min}$ in a rotatory shaker, the organic phase was removed and injected 135 in the chromatographic system. The same procedure was used to analyse cake and lees.

\section{Apparatus and chromatographic conditions}

138 GC/MS analysis of famoxadone was carried out on a Hewlett-Packard (Palo Alto, USA) HP 5890 139 Series II gas chromatograph system, equipped with a HP 7673 GC/SFC autosampler, a 19251A 140 capillary split-splitless injector and a GC-MS HP 5971 Series detector. The analytical column used 141 was a J\&W Scientific DB-17MS fused silica capillary column (Folsom, USA) with 15 m of length, $1420.25 \mathrm{~mm}$ of internal diameter and $0.15 \mu \mathrm{m}$ of film thickness. The injector temperature was set at $143300{ }^{\circ} \mathrm{C}$. The oven temperature program was as follows: initial temperature was kept at $200{ }^{\circ} \mathrm{C}$ for 1 $144 \mathrm{~min}$, increased to $300{ }^{\circ} \mathrm{C}$ at $10{ }^{\circ} \mathrm{C} \mathrm{min}{ }^{-1}$ and held at this temperature for $2 \mathrm{~min}$. Total run time was $14513.0 \mathrm{~min}$. The volume of sample was $2 \mu \mathrm{l}$, injected in splitless mode with splitless time of $1 \mathrm{~min}$. 146 Helium (99.9999\% purity) was used as carrier gas at constant flow rate of $0.8 \mathrm{ml} \mathrm{min}^{-1}$. The mass 147 spectrometer was operated in electron impact (65 eV of ion energy), with 10 minute solvent delay, 
149 The dwell time for the ion monitoring was $100 \mathrm{~ms}$ per ion. Selected monitoring ion (SIM) mode 150 was used. The ions utilized for quantification of famoxadone were 196, 224, 330 and $374 \mathrm{~m} / \mathrm{z}$.

\section{Model systems}

\section{Extraction procedure for grape waxes}

The extraction of the grapes waxes was carried out as previously (McDonald et al. 1993). Grape wax extraction was performed by the immersion of a known weight of untreated grapes in a known volume of chloroform, for $1 \mathrm{~min}$. The amount of waxes of the grape surface, expressed in $\mu \mathrm{g} \mathrm{cm}^{-2}$, was determined by evaporating an aliquot of $10 \mathrm{ml}$ of the chloroform extract to dryness and calculating the surface area of the fruit.

The model systems for photodegradation, codistillation, evaporation and thermodegradation were studied according to Garau et al. 2002. Briefly, three tests, presenting below, were done:

Test A - Evaporation and Thermodegradation. In a membrane of regenerated cellulose there was placed a solution of famoxadone with known concentration. After solvent evaporation, the membrane was placed in a $10 \mathrm{ml}$ dark screw-capped vial. This vial was putted in a thermostatic stove at $50{ }^{\circ} \mathrm{C}$ for $24 \mathrm{~h}$. Then, the vial was removed and placed in freezer for $5 \mathrm{~h}$ at $-20{ }^{\circ} \mathrm{C}$ to allow the condensation of famoxadone. After removing the vial from the freezer, the membrane was transferred to another vial with $5 \mathrm{ml}$ of ethyl acetate/hexane $(50: 50 \mathrm{v} / \mathrm{v})$ for the extraction of the remained residues of famoxadone. The first vial was also washed with the same amount of the solvent solution, allowing to measure the residues of famoxadone evaporated from the membrane. 172 amount of famoxadone of the control sample and the sum of the amounts of the famoxadone found 
173 in the membrane and in the vial of the heated sample was calculated. This value indicates the 174 amount of thermo-degradation of famoxadone.

175 Test B - Co-distillation. A regenerated cellulose membrane prepared in the same way of the Test A 176 was placed on the top of a $10 \mathrm{ml}$ dark vial, with a screw-closed cap with a hole in the middle, 177 containing $5 \mathrm{ml}$ of ultra-pure water previously weighted. This vial was placed in a thermostatic 178 stove in the same conditions of Test A, allowing the evaporation of the water and the co179 distillation of the famoxadone. After $24 \mathrm{~h}$, the vials were weighted to determine the amount of 180 water evaporated. The control sample was stored in the dark at room temperature. The loss of 181 famoxadone by codistillation was calculated by the difference between the amount of famoxadone 182 in the control sample and the amount of the famoxadone found in the membrane of the heated 183 sample estimated by GC-MS. For a suitable evaluation of codistillation, the possible losses of 184 famoxadone due to evaporation and thermo-degradation, determined with the Test A, must be 185 considered.

186 Test C - Sunlight Photodegradation. An aliquot of famoxadone solution at known concentration 187 was poured into Petri dishes with $5 \mathrm{~cm}$ of diameter and the solvent was allowed to evaporate, at 188 room temperature. The dishes were exposed to direct sunlight, removed at prefixed intervals and, 189 after re-dissolving the remained residues with $5 \mathrm{ml}$ of ethyl acetate/hexane $(50: 50 \mathrm{v} / \mathrm{v})$ injected for 190 GC- MS analysis. The control sample was stored in the dark at room temperature.

192 The Tests A, B and C were carried out with and without the presence of the epicuticular waxes 193 extracted from grapes, at the concentration of $0.37 \mu \mathrm{g} \mathrm{cm}{ }^{-2}$. Each experiment was replicated 4 194 times. 
197 During grapes maturation and before the treatment with Equation Pro, famoxadone was not 198 detected at the limit of $0.03 \mathrm{mg} \mathrm{kg}^{-1}$ in grapes. The limit of detection (LOD) for famoxadone, 199 calculated as three times the signal-to-noise ratio, was $0.02 \mathrm{mg} \mathrm{l}^{-1}$ for ethyl acetate/hexane (50:50 $200 \mathrm{v} / \mathrm{v}), 0.03 \mathrm{mg} \mathrm{kg}^{-1}$ for grapes and $0.04 \mathrm{mg} \mathrm{l}^{-1}$ for wine. The concentration of famoxadone residues 201 before treatment was, as expected, below the limits of detection of the method. After the referred 202 treatment, as reported in the Table 1, the concentration of famoxadone was $0.27 \pm 0.06 \mathrm{mg} \mathrm{kg}^{-1}$, 203 below the European LMR. It should be noted that three days after treatment levels of famoxadone 204 were $0.40 \pm 0.11 \mathrm{mg} \mathrm{kg}^{-1}$ and this is probably caused to a sample-to-sample variability. A decline 205 in residue levels was not observed until day 14 and then levels of famoxadone decreased until the 206 last determination near harvesting for wine production. The half-life time $\left(\mathrm{t}_{1 / 2}\right)$ of famoxadone, 207 calculated as pseudo-first order kinetics $\left(R^{2}=0.74\right)$, was $18 \pm 6$ days.

In wine production it was also important to understand the possible mechanism of disappearance of famoxadone residues. For this study, grapes after treatment, with a concentration of famoxadone 211 of $0.27 \pm 0.06 \mathrm{mg} \mathrm{kg}^{-1}$, were used. Before fermentation, the concentration of famoxadone residues 212 in must $\left(0.33 \pm 0.03 \mathrm{mg} \mathrm{kg}^{-1}\right)$ was the same of the grapes, indicating that it was distributed between 213 liquid and solid parts (Table 2).

After the fermentation process with and without the maceration process, famoxadone was not 216 detected in wines at the limit of $0.04 \mathrm{mg} \mathrm{kg}^{-1}$. During wine production without maceration, part of 217 the famoxadone residues were removed with the cake $\left(33 \% \times 0.31 \pm 0.04 \mathrm{mg} \mathrm{kg}^{-1}=0.10 \pm 0.01\right.$ $\left.218 \mathrm{mg} \mathrm{kg}^{-1}\right)$, and the remained part, after fermentation, was also removed with the lees $(5.8 \% \times 1.83 \pm$ $\left.2190.44 \mathrm{mg} \mathrm{kg}^{-1}=0.11 \pm 0.02 \mathrm{mg} \mathrm{kg}^{-1}\right)$. In wine production with maceration process, all the 220 famoxadone residues were separated with the cake and lees $32.5 \% \times 0.67 \pm 0.17 \mathrm{mg} \mathrm{kg}^{-1}=0.22 \pm$ 
$2210.06 \mathrm{mg} \mathrm{kg}^{-1}$ ) at the end of the fermentation process. In both cases, all the residues of famoxadone 222 were adsorbed to the solid parts.

Model system studies (Tests A, B and C) were carried out with and without grape epicuticular waxes $\left(0.37 \mu \mathrm{g} \mathrm{cm}^{-2}\right)$ because the latter could have an influence on the fate of pesticides on fruits (Cabras et al. 1997) enhancing or reducing $t_{1 / 2}$ of the active ingredient. Each test was carried out with the active ingredient and with the commercial formulation. The results obtained for the Test 228 A, provide an insight into the mechanisms of evaporation and thermodegradation, and Test B, 229 230 and for the commercial product, respectively. Concerning the Test A for famoxadone and for the 231 commercial product, no evaporation phenomena occurred in either case, with and without waxes. 232 In fact, at $50{ }^{\circ} \mathrm{C}$, which is on average the higher temperature found in the field during grape 233 maturation, all the residues remained in the membrane $(\mathrm{m})$. Considering the LOD of the method, 234 residues of famoxadone were not found in the vial (v) which contained the membrane. There were 235 no observed differences between the concentration of famoxadone in the control sample (c) and 236 the sum of the concentration in the vial and in the membrane indicating that there were no losses 237 by thermodegradation. In the Test B for the active ingredient and for the commercial product, it 238 was shown that co-distillation did not occur, either in the presence or absence of waxes. As shown 239 in Tables 3 and 4 no differences were observed comparing $\mathrm{c}$ and $\mathrm{m}$ values.

241 The results obtained for the Test $\mathrm{C}$, which examined the mechanisms of sunlight photodegradation, 242 are presented in Table 5 for the famoxadone and for the commercial product. Half-lives of 243 famoxadone ranged from 3.75 to 4.61 days with a standard error (SE) ranging from 0.02 to 0.99 244 and a $\mathrm{R}^{2}$ ranging from 0.78 to $0.99 . \mathrm{R}^{2}$ correlates the natural logarithmn ( $\mathrm{Ln}$ ) of the concentration with the time of exposure to solar radiation. In the Test $\mathrm{C}$ for the active ingredient it was observed 
246 that the presence of waxes did not influence the photodegradation process. Nevertheless, 247 photodegradation of the commercial product with waxes was slightly lower than without waxes. 248 This means that waxes in the presence of co-formulations could adsorb the radiation responsible 249 for the photodegradation.

251 Conclusions

252 This field degradation trial showed that famoxadone residues at the pre-harvest interval and during vinification were below the MRL $\left(2 \mathrm{mg} \mathrm{kg}^{-1}\right)$. During the wine-making process the fungicide is completely adsorbed in the cake and lees. Data from the models system experiments suggest that in real conditions evaporation, thermodegradation and co-distillation processes do not affect residue levels of famoxadone and the mechanism responsible for the disappearance of famoxadone was essentially that of photodegradation.

\section{Acknowledgements}

260 The authors wish to thank the FCT - Fundação para a Ciência e Tecnologia, in Portugal, for 261 financial support (SFRH/BD/4648/2001).

\section{References}

Bartlett DW, Clough JM, Godwin JR, Hall AA, Hamer, M, Parr-Dobrzanski, B. 2002. The strobilurin fungicides. Pest Management Science 58: 649-662.

267 Cabras P, Angioni A, Garau VL, Melis M, Pirisi FM, Minelli EV 1997. Effect of epicuticular 268 waxes of fruits on the photodegradation of fenthion. Journal of Agriculture and Food Chemistry 45: $3681-3683$ 
271 Cabras P, Angioni A, Garau VL, Melis M, Pirisi FM, Minelli EV, Cabitza F, Cabeddu M. 1997.

272 Fate of some new fungicides (cyprodinil, fludioxonil, pyrimethanil and tebuconazole) from vine to 273 wine. Journal of Agriculture and Food Chemistry 45: 2708-2710.

275 Cabras P, Angioni A, Garau VL; Pirisi, F. M.; Espinoza, J.; Mendoza, A.; Cabitza, F.; Pala, M.; 276 Brandolini, V. 1998. Fate of azoxystrobin, fluazinam, kresoxim-methyl, mepanipyrim and 277 tetraconazole from vine to wine. Journal of Agriculture and Food Chemistry 46, 3249-3251.

279 Cabras P, Angioni A, Garau VL, Pirisi FM, Cabitza F, Pala M, Farris GA. 2001. Fenhexamid 280 residues in grapes and wine. Food Additives and Contaminants 18: 625-629.

282 de Melo Abreu S, Caboni P, Cabras P, Alves A, Garau VL. 2005. GC-MS determination of 283 famoxadone in grapes and wines. Proceedings of $4^{\text {th }}$ International Congress on Food Technology, 284 Athens: vol. I, 329-333.

286 Garau VL, Angioni A, Aguilera Del Real A, Russo MT, Cabras P. 2002. Disappearance of 287 azoxystrobin, pyrimethanil, cyprodinil and fludioxonil on tomatoes in a greenhouse. Journal of 288 Agriculture and Food Chemistry 50: 1929-1932.

290 http://www.fao.org/documents/show_cdr.asp?url_file=/DOCREP/006/Y5221E/y5221e0e.htm..

292 Jernberg K. 2003. Famoxadone. In Handbook of residue analytical methods for agrochemicals. 293 DuPont Crop Protection. John Wiley \& Sons Ltd, 2:4: 11-24. 
1

3 4 5

295 Jordan DB, Livingston RS, Bisaha JJ, Duncan KE, Pember SO, Picollelli MA, Schwartz, RS, 296 Strnberg JA, Tang XS. 1999. Mode of action of famoxadone. Pesticide Science 55: 105-118.

298 Joshi MM, Sternberg JA. 1996. DPXP-JE874: A broad-spectrum fungicide with a new mode of 299 action. In Brighton Crop Protection Conference - Pest and Diseases: 21-26.

301 McDonald RE, Nordby HE, Mccollum TG. 1993. Epicuticular wax morphology and composition 302 are related to grapefruit chilling injury. Horticulture Science 28: 311-312.

Table 1. Concentration of famoxadone during grapes maturation and half-life time..

\begin{tabular}{ccc}
\hline Days after treatment & Concentration $\left(\mathbf{m g ~ k g}^{-\mathbf{1}}\right) \pm \mathbf{S D}$ & $\mathbf{t}_{\mathbf{1} / 2}($ days $\pm \mathbf{S E})$ \\
\hline 0 & $0.27 \pm 0.06$ & \\
\hline 3 & $0.40 \pm 0.11$ & \\
\hline 7 & $0.30 \pm 0.12$ & $18 \pm 6$ \\
\hline 14 & $0.22 \pm 0.11$ & \\
\hline 21 & $0.14 \pm 0.10$ & \\
\hline 28 & $0.16 \pm 0.07$ & \\
\hline
\end{tabular}

$306 \quad \overline{\mathrm{SD}}$ - standard deviation; SE - standard error 
322 Table 2. Fate of famoxadone during wine production.

\begin{tabular}{|c|c|}
\hline Sample & Concentration $\left(\mathrm{mg} \mathrm{kg}^{-1}\right.$ or $\left.\mathrm{mg} \mathrm{l}^{-1} \pm \mathrm{SD}\right)$ \\
\hline Grapes & $0.27 \pm 0.06$ \\
\hline Must & $0.33 \pm 0.03$ \\
\hline
\end{tabular}

\begin{tabular}{|c|c|c|c|}
\hline \multicolumn{2}{|c|}{ Vinification without maceration } & \multicolumn{2}{|c|}{ Vinification with maceration } \\
\hline Cake $(33.0 \%)$ & $0.31 \pm 0.04$ & Wine & $<0.04$ \\
\hline Wine & $<0.04$ & \multirow{2}{*}{$\begin{array}{c}\text { Cake and lees } \\
(32.5 \%)\end{array}$} & \multirow{2}{*}{$0.67 \pm 0.17$} \\
\hline Lees $(5.8 \%)$ & $1.83 \pm 0.44$ & & \\
\hline
\end{tabular}

$\mathrm{SD}$ - standard deviation 
Table 3. Results of Tests A (evaporation and thermodegradation) and B (codistillation) for the 339 famoxadone active ingredient, expressed in $\mathrm{mg} \mathrm{kg}^{-1} \pm \mathrm{SD}$.

\begin{tabular}{ccccc}
\hline & \multicolumn{2}{c}{ Test A } & \multicolumn{2}{c}{ Test B } \\
\cline { 2 - 5 } & $\begin{array}{c}\text { without } \\
\text { waxes }\end{array}$ & with waxes & $\begin{array}{c}\text { without } \\
\text { waxes }\end{array}$ & with waxes \\
\hline Control sample (c) & $2.00 \pm 0.06$ & $1.40 \pm 0.34$ & $2.10 \pm 0.20$ & $1.70 \pm 0.15$ \\
\hline Vial (v) & $<0.02(\mathrm{LOD})$ & $<0.02(\mathrm{LOD})$ & - & - \\
\hline Membrane (m) & $2.00 \pm 0.26$ & $1.40 \pm 0.29$ & $1.90 \pm 0.33$ & $1.80 \pm 0.10$ \\
\hline $\mathbf{c}-(\mathbf{v}+\mathbf{m})$ & n.s. & n.s. & n.s. & n.s. \\
\hline
\end{tabular}

341 n.s. - not significant 
Table 4. Results of Tests A (evaporation and thermodegradation) and B (codistillation) for the 359 commercial product, expressed in $\mathrm{mg} \mathrm{kg}^{-1} \pm \mathrm{SD}$.

\begin{tabular}{ccccc}
\hline & \multicolumn{2}{c}{ Test A } & \multicolumn{2}{c}{ Test B } \\
\cline { 2 - 5 } & $\begin{array}{c}\text { without } \\
\text { waxes }\end{array}$ & with waxes & $\begin{array}{c}\text { without } \\
\text { waxes }\end{array}$ & with waxes \\
\hline Control sample (c) & $1.34 \pm 0.01$ & $1.69 \pm 0.07$ & $1.43 \pm 0.05$ & $1.63 \pm 0.06$ \\
\hline Vial (v) & $<0.02(\mathrm{LOD})$ & $<0.02(\mathrm{LOD})$ & - & - \\
\hline Membrane (m) & $1.34 \pm 0.02$ & $1.61 \pm 0.15$ & $1.44 \pm 0.05$ & $1.61 \pm 0.05$ \\
\hline $\mathbf{c}-(\mathbf{v}+\mathbf{m})$ & n.s. & n.s. & n.s. & n.s.
\end{tabular}

n.s. - not significant 
Table 5. Results of Tests C (sunlight photodegradation) for the famoxadone and commercial 379 product, expressed in days \pm standard error $(\mathrm{SE})$.

\begin{tabular}{ccccc}
\hline & \multicolumn{3}{c}{ Test $\mathbf{C}$} \\
\cline { 2 - 5 } & \multicolumn{2}{c}{ without waxes } & \multicolumn{2}{c}{ with waxes } \\
\hline Famoxadone & Equation Pro & Famoxadone & Equation Pro \\
\hline $\mathbf{t}_{\mathbf{1} / \mathbf{2}}$ (days) & $4.41 \underline{\underline{0.99}}$ & $3.75 \pm \underline{\underline{0.58}}$ & $4.26 \pm 0.02$ & $4.61 \pm 0.43$ \\
\hline $\mathbf{R}^{\mathbf{2}}$ & 0.78 & 0.91 & 0.99 & 0.97 \\
\hline
\end{tabular}


